International Journal of Advanced Academic Research (Sciences, Technology and Engineering) | ISSN: 2488-9849

Vol. 7, Issue 2 (February, 2021) | www.ijaar.org

Journal DOI: $\underline{\text { www.doi.org/10.46654/ij.24889849 }}$

Article DOI: www.doi.org/10.46654/ij.24889849.e725

\title{
TREATMENT OF TEXTILE EFFLUENT USING NATURALLY PREPARED COAGULANT FROM MORINGA OLEIFERA SEED
}

\author{
Umma Muhammad ${ }^{1}$, Amina Auwal Umar² and Ikwuagwu Ugonna Leonard ${ }^{3}$ \\ ${ }^{1-2}$ Dept of Science Laboratory Technology, School of Technology, Kano State Polytechnic. \\ ${ }^{3}$ Dept of Chemistry, Faculty of Science and Technology, National Open University Nigeria.
}

(Corresponding author: umjidda58@gmail.com)

\begin{abstract}
This investigation is intended for Chemical Oxygen Demand (COD), Total Dissolved Solid (TDS), Biological Oxygen Demand (BOD), Conductivity, Dissolved oxygen, Absorbance, PH and turbidity reduction from textile industrial produce effluents that are highly complex and characterized. In this study coagulant using Moringa Oliefera seed was used to reduce the suspended and colloidal materials responsible for turbidity of the waste water. The seed powder was used as a natural coagulant to reduce turbidity, the test were carried out using textile effluent with conventional test apparatus. Various result were obtained by increasing dosage of Moringa Oleifera seed powder from $4 \mathrm{~g}$ to $24 \mathrm{~g}$ optimum dosage for reduction of COD, BOD, TDS, Turbidity, Conductivity, Absorbance and D.O was determined. It was observed that the highest dose which is $24 \mathrm{~g}$ has a greater efficiency in reduction of all parameters tested with Ph of 6.48, COD 46mg/L, BOD 12mg/L, and Conductivity 360MSCm ${ }^{-1}$, TDS 212 $\mathrm{mg} / \mathrm{L}$, Turbidity $8 N T U, D O 4.7$ and absorbance of 0.65. Moringa Oleifera seed showed potential in industrial textile effluent treatments among others.
\end{abstract}

Keywords: Effluents, Moringa, conductivity, Turbidity, Absorbance 


\section{Introduction}

Pure water is colorless, odorless and tasteless and so common that you probably never think about how unique it is and how essential to life. Drinking water as pure as it is may be infected by chlorine used during the treatment of that water or may contain particles gotten from pipes and soldered joints during supply of the water to the environment or contaminated by dropping of waste materials into water bodies and thus has increased / being on the increase since the advent of industries - Tannery, Textile, Chemical industries and many more (Flaten, 2001).

In view of growing awareness of pollution problems, dispersal of organic contamination in the environment is becoming a matter of concern. Ever increasing use of chemical and related compounds in each and every field of industry and even agriculture summons an urgent need of method for their effective removal from water and waste water. Increased population and modernized civilization trend gave rise to blooming of textile and chemical sectors in some parts of the world, for example in India, an estimate shows that textile account for $14 \%$ of India's Industrial production and around $27 \%$ of its export earnings (Ranganathan et al., 2007).

Traditional methods of dealing with waste water consist of various combinations of biological, physical and chemical methods. Biological treatments of dyeing waste water are cheaper than other methods, but it is less efficient for decolonization due to toxicity of the waste water and the need for an aeration system. Although the dyestuff and coloured material in waste water can be effectively destroyed by advanced chemical oxidation such as $\mathrm{UV} / \mathrm{H}_{2} \mathrm{O}_{2}$ and adsorption using activated carbon, the cost of these method are relatively high for an economically feasible treatment of the textiles waste water (Kobya et al., 2006).

Coagulation can be interpreted as the conversion of colloidal and dispersed particles into small visible flock upon addition of a simple electrolyte (coagulant). Increasing the concentration of the electrolyte results in a compression of the electrical double layer surrounding each suspended particle and a decrease in the magnitude of the repulsive interactions between particle and destabilization of the particles.

Moringa Oliefera is a fast growing, deciduous tree that can reach a height if $10-12$ metres (32 40 feets) and trunk diameter of 45 centimeters ( 1.5 feets). Moringa seed cake obtained as a byproduct of pressing seeds to obtain oil is used to filter water using flocculation to produce portable water for animal or human consumption. Moringa seed contain dimeric cations proteins which absorb and neutralize colloidal charges in turbid water causing the colloidal particles to clump together, making the suspended particles easier to remove as sludge by either settling or filtration. Moringa seed cake removes most impurities from water, this use of particular interest for being nontoxic and sustainable compared to other materials in moringa -growing regions where drinking water is affected by pollutants (Hellsing et al., 2013).

The moringa tree is grown mainly in semiarid, tropical and subtropical areas corresponding in the United States to USDA hardness zones 9 and 10. It tolerates a wide range of soil conditions but prefers a neutral to slightly acidic ( $\mathrm{Ph} 6.3$ to 7.0), well drained sandy or loamy soil. In water logged soil, the roots have a tendency to rot, moringa is a sun and heat loving plant, this does not tolerate freezing or frost, moringa is particularly suitable for dry regions as it can be grown using 
Journal DOI: www.doi.org/10.46654/ij.24889849

Article DOI: $\underline{\text { ww.doi.org/10.46654/ij.24889849.e725 }}$

rain water without expensive irrigation techniques (Ted, 2011). The immature seed pods called "drumstick" are commonly consumed in south Asia. They are prepared by parboiling and cooked in a curry until soft (Elizabeth, 2001). The seed pods / fruits even when cooked by boiling remain particularly high in vitamin (which may be degraded variably by cooking) and are also a good source of dietary fibre, potassium, magnesium and manganese (Conde, 2012). The seeds, sometimes removed from more mature pods and eaten like peas or roasted like nuts, contain high levels of vitamins C and moderate amounts of B vitamins and dietary minerals (Elizabeth, 2001).

The leaves are the most nutritious part of the plant, being a significant source of B vitamins, vitamins $\mathrm{C}$, provitamin A as beta-carotene, vitamin $\mathrm{K}$, Manganese and protein among other nutrients per $100 \mathrm{~g}$ fresh weight, cooked moringa leaves are considerable sources of these same nutrients. Some of the calcium in moringa leaves is bound as crystals of calcium oxalate through at levels $1 / 25^{\text {th }}$ to $1 / 45^{\text {th }}$ of that found in spinach, which is a negligible amount (Olson and Carquist, 2001). The leaves are cooked and used like spinach and are commonly dried and crushed into a powder used in soup and sauces.

Juice from the leaves is believed to have a stabilizing effect on blood pressure and is used to treat anxiety. It is believed to control glucose level in cases of diabetes. Mixed with honey and followed by a drink of coconut milk 2 or 3 times daily, leaves are used as remedy for diarrhea, dysentery and colitis. Leaf juice, sometimes with carrot juice added is used as a diuretic. Eating leaves were recommended in cases of gonorrhea because of diuretic action. Leaves and buds are rubbed on the temples for headache. A poultice is made from fresh leaves and applied to reduce glandular swelling. Leaf juice is used as a skin antiseptic and to treat fevers, bronchitis, eye and ear infection, scurvy and catarrh (pure healing foods 2018).

\section{Textile Waste}

Himanshu and Vashi (2012) found out that the textile dyeing industry consumes large quantities of water and produces large volumes of waste water from different processes in dyeing and finishing processes. The low cost, easily available naturally prepared coagulants like surjana seed powder (SSP), maize seed powder (MSP) and chitosan as an ideal alternative to recent expensive coagulant methods for Congo red (CR) dye removal has been investigated in their study. Various process parameters like $\mathrm{PH}$, coagulant dose, flocculation time and temperature and also its optimization were exploited. The maximum percentage for CR removal was found to be 98.0 , 94.5 and 89.4 for SSP, Chitosan and MSP, respectively at PH 4.0 coagulant dose of $25 \mathrm{mg} / \mathrm{L}$, flocculation time 60minutes and temperature of $340-$

The sludge volume index (SVI) and turbidity were calculated for these parameters including process optimization - SSP found more preferable for CR removal and Chitosan was a better coagulant, which corresponds to SVI that the other coagulants investigated.

Patel and Vashir (2013) found that the waste water generated by the textile industry is rated as the pollutant among all industrial sectors considering both volumes discharged and effluent composition, in their investigation for C.O.D and color removal from textile waste water using naturally prepared coagulants i.e surjana seed powder (SSP), maize seed power (MSP) and Chitosan. Effect of coagulant dose, flocculation time and temperature has been studied, the 
Journal DOI: www.doi.org/10.46654/ij.24889849

Article DOI: www.doi.org/10.46654/ij.24889849.e725

sludge volume index (SVI) and turbidity were examined for various effects, SSP was more effective than Chitosan and MSP for the removal of COD and color also Chitosan was more effective than SSP and MSP considering SVI and turbidity. Maximum percentage reduction corresponds to 75.6 and 62.8 was obtained for removal of COD and color respectively using surjama seed powder.

Parameswari, (2014) assessed the impact of textile and dye industrial effluent on soil and crops, the pot culture experiment was carried out with maize crop to determine the effect of dye and textile factory effluent in combination with amendments (poultry manure, green leaf manure, bio compost, vermin compost) revealed that application of (ETP sludge at $5 \mathrm{t} \mathrm{ha}^{-1}+$ poultry manure $5 \mathrm{t} \mathrm{ha}^{-1}+$ NPK increased the soil organic carbon; available NPK, CA, MG and heavy metals like chromium in soil under treated effluent irrigation compared to river water irrigation. The total chromium content ranged from 0.50 to $13.25,1.00$ to 36.52 and 1.65 to $32.52 \mathrm{mgkg}^{-1}$ at vegetative stage, flowering stage and at harvest stages respectively under effluent irrigation. However, it did not produce any toxic effects to the crops, this showed that the treated effluent could be safely used for irrigation along with poultry manure at $5 \mathrm{t} \mathrm{ha}^{-1}$ and NPK. However, continuous monitoring of the soil and ground water quality parameters are essential to suggest suitable remediation measures when treated textile and dye factory effluent is continuously use for irrigation.

\section{Effluent}

Effluent is an out flowing of water or gas from a natural body of water or from a human made structure. Effluent in the artificial sense is in generally considered to be water pollution such as out flow from a sewage treatment facility or the waste water discharge from industrial facilities (James, 1985).

Waste water is water that has been used and must be treated before it is released into another body of water so that it does not cause further pollution of water sources. Waste water comes from a variety of sources, everything that an individual flushes down the toilet or rinses down the drain is waste water. Rainwater and runoff along with various pollutants go down street gutters and eventually end up at a wastewater treatment facility; wastewater can also come from agricultural and industrial sources. some wastewaters are more difficult to treat than others' for example, industrial waste water can be difficult to treat, where as domestic wastewater is relatively easy to treat (though it is increasingly difficult to treat domestic waste) due to increased amounts of pharmaceuticals and personal care products that are found in domestic wastewater.

Industrial wastes are highly variable in both quality and quantity depending on the products produces. Nearly every industry has its own particular waste disposal problems and the volume and strength of effluent vary from industry to industry.

This paper will be based on the use of naturally prepared coagulant from Moringa Oliefera in order to treat effluent from the textile industry, the parameters to be checked are: C.O.D, T.D.S, B.O.D, conductivity, dissolved oxygen, absorbance, $\mathrm{PH}$ and Turbidity. 
Journal DOI: www.doi.org/10.46654/ij.24889849

Article DOI: www.doi.org/10.46654/ij.24889849.e725

\section{Materials and Methods}

The apparatus and reagents used in this experiment are: Beakers, Conical Flask, Sample Bottle, Measuring Cylinder, Grinder, Uv - Machine, Conductivity Machine, Glass Rod, Spatula, Funnel, Portable data logging spectrophotometer, PH Meter, TDS Meter, Turbidity Meter, Micro Sieve, Ethanol, Distilled water.

\section{Experimental design}

The waste water sample was gotten from African Textile Manufacturers, in a gallon and kept in the refrigerator to preserve the characteristics of waste water. The waste water was analyzed as per standard method (APHA 1992) for treatment of the waste water samples, the required dosages of the coagulant was added to a small portion of the waste water sample, stirred well and kept in contact for the requisite flocculation time and at the desired temperature under investigation and then filtered Important physic - chemical characteristics VIZ C.O.D and color was determined before and after treatment. To determine the effect of different amounts of naturally prepared coagulant - moringa seed powder using organic solvent - ethanol, the wastewater was treated with 4.0, 8.0, 12.0, 16.0, 20.0 and 24.0g of each coagulant for constant flocculation time (60minutes) at constant room temperature. The chemical used was of analytical reagent grade, also the characterization of sludge produced was measured in terms turbidly was determined using standard method for all process parameters, the process parameters determined are; Turbidity, C.O.D, B.O.D, T.D.S, PH, Conductivity, Absorbance and dissolved oxygen.

\section{Methods}

\section{Collection and preparation of the sample}

The moringa seed was collected from Sabon Gari market Fagge Local Government Area, Kano State. Moringa seed was selected to remove dirt, the dried seeds were crushed and powdered and sieved through $200 \mathrm{~mm}$ aluminum sieves and used as coagulant.

The seed of moringa was used, the seeds were grounded to fine powder by a grinder $100 \mathrm{~g}$ of the seed powder was soaked in $500 \mathrm{ml}$ of $99 \%$ ethanol and allowed to stay at room temperature for the period of 48 hours with stirring from time to time. The solution was stirred using a magnetic stirrer for the period of 30minutes, filtered through the Whitman filter paper which was allowed to dry. Oil was removed by allowing the ethanol escape by exposing residue to air; the dried sample was stored for the coagulation experiment.

Different grams of the coagulant (moringa seed dried sample) were weighed for the coagulation experiment, 4g, 8g, 12,16, 20g and $24 \mathrm{~g}$ of the seed powder were weighed and dissolved in $100 \mathrm{ml}$ each of the effluent sample in conical flask which was agitated for the period of 30 minutes with constant stirring at room temperature allowed to settle for 15 minutes, filtered through the Whitman filter paper, from which different clear effluent samples was obtained. This was then followed by testing PH, conductivity, turbidity, total dissolved solid, COD and BOD of each treated sample respectively. 
Journal DOI: www.doi.org/10.46654/ij.24889849

Article DOI: www.doi.org/10.46654/ij.24889849.e725

\section{Determination of conductivity}

The conductivity was determined using electrical conductivity apparatus. The measuring cell was cleaned with distilled water and then sample was poured and the connecting cable was place into the measuring cell socket. The temperature dial was set to the temperature of the water sample and the selector switch was turned to the anticipated range of measurement, the activator was held button down and slowly rotating measuring dial unit the balance indicator moved to the center scale and the dial setting was read when this occurred, which was multiplied by the range factor.

\section{Determination of turbidity}

Turbid meter was calibrated using an appropriate standard (10, 100, 500, and 1000). The sample cell was filled with the sample and replaced into the turbid meter, the value was read off from the screen (Training guide for water quality testing and control course C.O.D e 1011) (APHA 1992).

\section{Ph measurement}

The PH meter was warmed for 15-20 minutes; the electrode was removed from distilled water and rinsed with fresh distilled water then wiped dry. The meter was standardized using buffer solution at the temperature specified $\left(20\right.$ or $\left.25^{\circ} \mathrm{C}\right) \mathrm{PH}$ knob was switched off and the electrode was removed from the second buffer, this was rinsed thoroughly and wiped with soft tissue, it was inserted into the sample and $\mathrm{PH}$ knob was switched on and the readings were recorded after this the electrode was then rinsed and immersed in a distilled water (APHA - 1992).

\section{Tds measurement}

$>$ Press the mode key until the icon is above the TDS enunciator

$>$ Immerse the tip or beyond the vent holes of the probe into $80 \mathrm{ml}$ of the effluent sample and agitate the probe vertically. If the sample is not flowing or being stirred make sure air bubbles are not entrapped near the temperature sensor.

$>$ Allow the reading to stabilize and record the measurements.

(APHA - 1992)

\section{Cod measurement}

The spectrophotometer was set to C.O.D (Chemical Oxygen demand) high range and calibrated. A blank was placed into the adapter and covered in the spectrophotometer which was then zeroed to $0 \mathrm{mgl} \mathrm{L}$, C.O.D high range for sample digestion from 0 - 1500ppm range, small quantity of the effluent sample was put into the vial and heated to $95-100^{\circ} \mathrm{c}$. The heated sample was transferred into a bottle and placed in the adapter and the read button was pressed after which the reading was displayed and recorded (APHA - 1992).

\section{BOD / DO determination}

Effluent was treated and dilution was made, DO of effluent was taken and solution was incubated for 5days. The diluted sample was transferred to glass stopper BOD bottle and 
temperature was regulated to about $20^{\circ} \mathrm{c}$. Appropriate nitrification inhibitor was added to the sample, the same process was done using blank solution. The $\mathrm{DO}_{5}$ of the sample(s), blank were measured and their BOD was determined using;

$$
\begin{gathered}
\text { BOD5 }=\underset{\text { Sample }}{\left[\left(\mathrm{CDO}_{\mathrm{o}}-\mathrm{DO}_{5}\right)-\left(\mathrm{DO}_{\mathrm{o}}-\mathrm{DO}_{5}\right)\right] \times \mathrm{X}} \\
\mathrm{X}=\text { Dilution factor }
\end{gathered}
$$

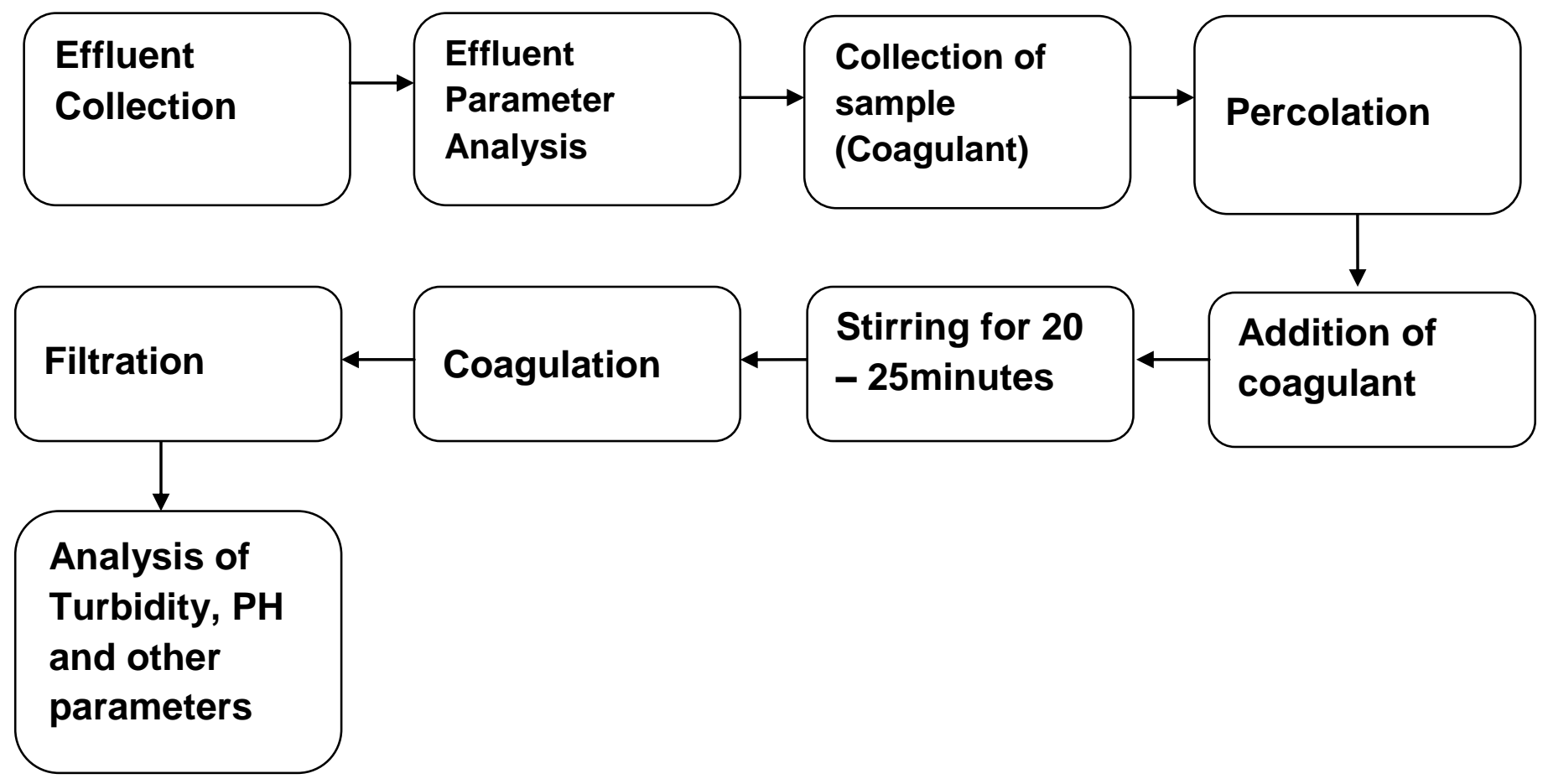

Fig 1: Flow chart of the experimental design 
Journal DOI: www.doi.org/10.46654/ij.24889849

Article DOI: www.doi.org/10.46654/ij.24889849.e725

\section{Results and Discussion}

Table 1: Initial characteristics of the effluent compared with WHO standard

\begin{tabular}{|l|l|l|l|}
\hline S/NO & PARAMETERS & EFFLUENT VALUE & WHO STANDARD \\
\hline 1 & TURBIDITY & 65 & $30 \mathrm{NTU}$ \\
\hline 2 & C.O.D $(\mathrm{mg} / \mathrm{l})$ & 220 & $80 \mathrm{mg} / \mathrm{l}$ \\
\hline 3 & D.O $(\mathrm{mg} / \mathrm{l})$ & 3.9 & $2-4 \mathrm{mg} / \mathrm{l}$ \\
\hline 4 & T.D.S $(\mathrm{mg} / \mathrm{l})$ & 1100 & $2000 \mathrm{mg} / \mathrm{l}$ \\
\hline 5 & PH & 4.6 & $6-9$ \\
\hline 6 & B.O.D $(\mathrm{mg} / \mathrm{l})$ & 78 & $30 \mathrm{mg} / \mathrm{l}$ \\
\hline 7 & ABSORBANCE $(\lambda \max )$ & 1.114 & 0.5 \\
\hline 8 & CONDUCTIVITY $\left(\mu 5 \mathrm{~cm}^{-1}\right)$ & 3004 & $1000 \mathrm{mg} / \mathrm{l}$ \\
\hline
\end{tabular}

TABLE 2: Characteristics of treated effluent with respect to coagulant dosage

\begin{tabular}{|l|l|l|l|l|l|l|l|}
\hline S/NO & PARAMETERS & $\mathbf{4 g}$ & $\mathbf{8 g}$ & $\mathbf{1 2 g}$ & $\mathbf{1 6 g}$ & $\mathbf{2 0}$ & $\mathbf{2 4 g}$ \\
\hline 1 & PH & 4.65 & 4.72 & 4.74 & 5.38 & 5,50 & 6.48 \\
\hline 2 & C.O.D (mg/l) & 228 & 184 & 142 & 88 & 68 & 46 \\
\hline 3 & B.O.D (mg/l) & 78.5 & 64 & 42 & 34 & 26 & 12 \\
\hline 4 & CONDUCTIVITY & 3000 & 2210 & 1240 & 910 & 640 & 360 \\
\hline 5 & T.D.S (mg/l) & 1090 & 930 & 722 & 516 & 330 & 212 \\
\hline 6 & TURBIDITY & 43 & 32 & 25 & 17 & 14 & 8 \\
\hline 7 & ABSORBANCE & 0.914 & 0.631 & 0.322 & 0.210 & 0.110 & 0.065 \\
\hline 8 & D.O (mg/l) & 3.9 & 4.0 & 4.3 & 4.4 & 4.6 & 4.7 \\
\hline
\end{tabular}

\section{Discussion}

Coagulant dosage variations from $4 \mathrm{~g}$ to $24 \mathrm{~g}$ weight performance on effluent at optimum condition were determined and each parameters of test carried out are as shown in the table of results. The result indicated that certain dose of the coagulant resulted in a poor performance and some gave a good performance. A dosage of $24 \mathrm{~g}$ gave the optimum result for all coagulant parameters tested as shown in table 2 . 
Journal DOI: www.doi.org/10.46654/ij.24889849

Article DOI: www.doi.org/10.46654/ij.24889849.e725

The result of tests on the effluent alone serving as control is as shown in table 2 . The $\mathrm{Ph}$ of the investigated textile mill effluent was found to be 4.8 , the colour unit $1.114 \lambda \max , \mathrm{COD}, \mathrm{BOD}$, D.O, TDS and Turbidity were $220 \mathrm{mg} / \mathrm{l}, 78 \mathrm{mg} / \mathrm{l}, 4.5 \mathrm{mg} / \mathrm{l}, 1100 \mathrm{mg} / \mathrm{l}$ and $65 \mathrm{NTU}$ (Nephelometric Turbidity Unit) respectively. The average value of electrical conductivity was found to 3004 $\mu \mathrm{scm}{ }^{-1}$

Coagulant dosage is one of the important factors that have been considered to determine the optimum condition performance of coagulants in coagulation and flocculation. Essentially, insufficient dosage or overdosing would result in the poor performance in flocculation; therefore it is significant to determine the optimum dosage in order to minimize the dosing cost and sludge formation and also to obtain the optimum performance in treatment. The effect of coagulant doses, 4 to $24 \mathrm{~g}$ for the removal of C.O.D and color from dyeing mill waste water maintaining temperature of $308 \mathrm{k}$ and flocculation time $660 \mathrm{~mm}$ using MSP as presented in the table of results will be discussed in detail.

The World Health Organization (WHO) has a standard for the treatment of effluent as shown in table 1 so that if the treated effluent result does not correspond to their standard will always call for a check or further purification process before it can be disposed to any water body, the standard will not be stated but used as basis for the discussion of result presented.

Turbidity is the cloudiness or laziness of a fluid caused by individual particles (total suspended or dissolved solid) that are generally invisible to the naked eye. The turbidity will be high if the total suspended solid were not absorbed by the coagulant and from the result gotten for this (before and after the treatment $65 \mathrm{NTU}$ and $8 \mathrm{NTU}$ respectively for $24 \mathrm{~g}$ - the best of all the result gotten after treatment) means that the coagulant was able to work on both total dissolved solid and suspended solids and in comparison to WHO standard shows it within the accepted ranges of values.

The $\mathrm{PH}$ value ranges $0-14$, acidic values $0-6.9$ neutral values 7-7.9 and alkaline value $8-14$, on treating the effluent the value was increase from 4.5 to 6.48 for $24 \mathrm{~g} / \mathrm{l}$ (the best) which indicates that the moringa acted on the PH by increasing its value which is in accordance to WHO standard.

The conductivity of the effluent before treatment $\left(3004 \mu \mathrm{scm}^{-1}\right)$ was very high and after treatment it reduced to a value far lesser giving the result of $360 \mu \mathrm{scm}^{-1}$ at coagulant dosage $24 \mathrm{~g}$ which is far lesser than the effluents conductivity before treatment and in accordance to WHO standard.

The Total Dissolved Solids of $212 \mathrm{mg} / \mathrm{l}$ due to the coagulation activity of the moringa Oliefera seed. The initial characteristics of the effluent shows it was turbid but after coagulation it became clear. A clear effluent was obtained with $24 \mathrm{~g}$ optimum; the result shows that the turbidity of the treated effluent reduced relatively by increase in dosage of the coagulant when compared with the untreated effluent and this value obtained is in accordance with WHO standard.

Dissolved oxygen is the amount of oxygen that is available for living organism, from the result there was an increase as the coagulant dosage increased from $4 \mathrm{~g}-24 \mathrm{~g}$, the dissolved oxygen increased form $3.9 \mathrm{mg} / \mathrm{l}$ to $4.7 \mathrm{mg} / \mathrm{l}$ best value at $24 \mathrm{~g}$. 
Journal DOI: www.doi.org/10.46654/ij.24889849

Vol. 7, Issue 2 (February, 2021) |www.ijaar.org

Article DOI: www.doi.org/10.46654/ij.24889849.e725

Chemical Oxygen Demand for reduction and oxidation processes as they are important processes in any water body. The C.O.D concentration after treatment decreased with increase in coagulant dosage from $4 \mathrm{~g}-24 \mathrm{~g}(228-46 \mathrm{mg} / \mathrm{l})$, the best C.O.D concentration was found at coagulant dosage $24 \mathrm{~g}$ which gave $46 \mathrm{mg} / \mathrm{l}$ and falls with range of WHO standard.

Biological Oxygen Demand necessary for metabolic processes to take place. Initially the B.O.D before treatment was found to be $78 \mathrm{mg} .1$ but after treatment it was found $12 \mathrm{mg} / \mathrm{l}$ at optimum dosage $24 \mathrm{~g}$ and value was within range of WHO standard.

The absorbance which is the color of the treated effluent decreased relative to dosage increase the initial blue color of the effluent disappeared after coagulant at $24 \mathrm{~g}$ optima, dosage.

\section{Conclusion}

The feasibility of textile waste using naturally prepared coagulant (Moringa Oliefera) in order to remove some essential characteristic was analyzed. The results showed that moring Oliefera seed has the efficiency of reducing COD, BOD, TDS, conductivity, turbidity and absorbance of the effluent to determine the optimum condition for the performance of the coagulant, dosage was varied from $4 \mathrm{~g}-24 \mathrm{~g}$ for each parameter tested since insufficient dosage or overdosing would result in poor performance of the coagulant. The optimum dosage of $24 \mathrm{~g} / 100 \mathrm{ml}$ showed a very good performance by decreasing acidity and all the parameter tested. The blue colour of the effluent disappeared and the odour was removed. Hence, it is concluded that the seeds of moringa Oliefera which readily available plant in many parts of the world can be effectively used as a coagulant for treating textile effluents. 


\section{Reference}

APHA (American Public Health Association - 1992), "Standard methods for the examination of water and wastewater", $18^{\text {th }}$ Edition, Fed. Reg. 44:27362-27375 Washington, DC.

Chiwendu, P.A (2014), "Treatment of Textile effluent using naturally prepared coagulant from Zea Mays”, research, BUK Kano Page 1-29.

Conde Nast (2012) "Horseradish - tree, Pods, cooked, boiled, drained, without salt" Retrieved $6^{\text {th }}$ May 2013.

Elizabeth Schneider (2001) “Vegetables from Amaranth to Zucchini”. The essential reference Harper Collins page 318.

Flaten T.P (2001. 'Aluminum as risk factor in Alzheimer's disease with emphasis on drinking water”. Brain research bulletin. Volume 55 (2): page 187 - 196.

Hellsing Maja S., Kwaambwa, Habauka M., Nermark, Fiona M., Nkoane, Bonang B.M, Jackson Andrew J., Wasbrough, Matthew J. Berts Ida, Porcar, Lionel, Rennie, Adrain R. (2013). "Structure of flocs of latex particles formed by addition of protein from moringa seeds". Colloids and surfaces A. Physicochemical and Engineering aspect 460 Page 460 $-467$.

Iqbal Shahid, Bhanger M.i (2006) "Effect of season and production location on antioxidant activity of moringa oleifera leaves grown in Pakistan”. Journal of food composition and analysis. 19 (6-7) page $544-551$.

James W. (1985) “Industrial Waste Water Treatment Technology": $2^{\text {nd }}$ Edition. Buffer with publishers, London, page 191 - 196.

Kobya M., Demirbas E., Can O.T and Bayramoglu M. (2006), "Treatment of Levafix Orange Textile dye solution by electro coagulation”, J. Hazard Mater, Volume 132 (2 - 3), Page $183-188$.

Leone A, Spada A Battezzati A, Schiraldi A, Aristil J, Bertoli S (2015). "Cultivation Genetic Ethno pharmacology, Photochemistry and Pharmacology of moringa Oliefera leaves": An overview "Int. Journal Mol. Sci 16 (6) Page 12791 - 835.

Mandloi M., Chaudhari S. and Folkard G.K (2004), "Evaluation of natural coagulants for direct filtration environmental technology”. Volume 25 (4), Page 481 - 489.

Metcalf E (1972) “Waste water engineering". $2^{\text {nd }}$ edition; McGraw Hill book Company. New York. Page $156-158$.

Olson M.E Carlquist S (2001). "Stem and root anatomical correlations with life from diversity, ecology and systematic in moringa (moringaceae)". Botanical Journal of the Linnaean society. 135 (4) page $315-348$ 
Journal DOI: www.doi.org/10.46654/ij.24889849

Article DOI: $\underline{\text { www.doi.org/10.46654/ij.24889849.e725 }}$

Parameswari M. (2014), Textile and dye industry effluent, sludge and amendments on heavy metals chromium, nickel, cadmium and lead status of maize cultivated soil", International Journal of Applied and Natural Science (IJANS) Volume 3, issue 2, Pages 53 -62.

Patel H., Vashi R.T. (2012), "Removal of Congo Red Dye from it aqueous solution using natural coagulants", J. Saudi Chemical Society volume 16 (2), Page $351-356$.

Raghuwanshi P.K, Madhol M. Shrama A.J., Malviya H.S., Chadari S. (2002), "Improving filtrate quality using agro based materials as coagulant aid, water quality resource" J. Caril, Volume 37, page $745-756$.

Ranganathan K., Karunagaran K. Sharma D.C. (2007), "Recycling of waste waters of textile dyeing industries using advanced treatment technology and cost analysis" - case studies, resource conservation recycle. Volume 50 (3), Page $306-318$.

Ted Radovida (2011) C.R Elevitch, ed "farm and forestry production and marketing profile for moringa (revised February 2011)" specialty crops for pacific island agro forestry Halualoa, Hawai: Permanent Agriculture resources.

WHO (2010) International Standard for drinking water guidelines for water quality, Geneva. www.purehealingfood.com>moringainfo2018. 